\title{
Unlawfulness in Western European Tort Law
}

\author{
Martín García-Ripoll \\ University of Murcia, Murcia, Spain \\ Email: martinga@um.es
}

Received 26 May 2015; accepted 10 June 2015; published 15 June 2015

Copyright (C) 2015 by author and OALib.

This work is licensed under the Creative Commons Attribution International License (CC BY). http://creativecommons.org/licenses/by/4.0/

\section{(c) (i) Open Access}

\begin{abstract}
In the wake of the German Civil Code (BGB), the codes of different countries of Western Europe include an apparently distorting requisite for an action in tort, which is the unlawfulness. This paper aims to clarify its original meaning and the possibilities of accepting it in jurisdictions where its law does not require expressly that element, including those of Common Law. Before moving directly into the problem, a clarification seems necessary for Common Law scholars, for this paper is focused on a scientific European issue. In Common Law, it is debatable whether there is a general tort law or different torts, but no matter the opinion of the different authors is, each tort is supposed to have its own requisites. In contrast, in Continental Law, the trend is to establish common requisites for all torts (although it is distinguished between "normal" and strict liability), and to insert subsequently nuances when dealing with special group of cases. This paper deals with one of these general elements of an action in tort in some codified systems: the unlawfulness, but without rejecting its usefulness in Common Law jurisdictions.
\end{abstract}

\section{Keywords}

Tort Law, Unlawfulness, Wrongfulness, Fault, Liability of Minors and Mentally Ill Persons

Subject Area: Law

\section{Introduction}

Unlawfulness means against the law, but this is a purely formal approach. We need to give certain content to that term. However, the task is not easy because the concept constitutes, deep down, a matter of philosophy of law, and, anyway, has very possible different meanings in law. Let us take some examples just from private law:

-In some jurisdictions, the decedent has to leave a part of his estate to some relatives; to add up each relative's part, law usually takes into account gifts inter vivos. Let us imagine that a person who is in a wealthy situation makes a lot of gifts, thinking that she has still enough assets to observe the law. Later on, because of a financial crisis she comes into a very bad economic situation, so that the part left to her relatives in the will is not enough; it can be said that the will is unlawful, but clearly in a very different sense to that which we are talking about. 
-Likewise, we can consider that possession in good faith is an unlawful act; but this is rather a problem of unjust enrichment. E.g., if a possessor in good faith has not caused any damage to the plot of land she possesses, and, on the contrary, has improved the field in order to have a better harvest, tort law has nothing to say here. But, depending on the jurisdictions, perhaps the possessor has to disgorge the fruits.

In the field of torts, what is fervently discussed is whether the unlawfulness requisite refers to the conduct of the wrongdoer or to the result, i.e. the damage.

German scholars usually put the start of this controversy in the works of a 19 century criminalist, Adolf Merkel, and the very well known jurist Rudolph von Jhering. The background of the debate was the different conceptions of unlawfulness in which German criminalists of that age were developing and Hegel's classification of the different acts against the law was established.

Following his famous dialectic scheme, Georg W. F. Hegel (1770-1831) thinks that "existence in general of free will is what is meant as law. Law is, therefore, in general, freedom as idea" ( $(29$; thesis); such freedom appears specially through property $(\S 41)$ and contract $(\S 72)$. But if particular freedom is opposed to universal freedom, we are before unlawfulness ( $\$ 82$; antithesis). Finally, law is strengthened through the negation of that negation, that is, through either punishment or redress of damage (synthesis; § 97): "The breach of law as law is actually a positive being, external, but void in itself. The sign of its invalidity is the destruction of that breach...; law as its necessity in itself- 'sich mit sich'-is achieved by the removal of its breach" [1].

In the field of unlawfulness (Unrecht), the idealist philosopher distinguishes among unintentional unlawfulness (unbefangen), fraud (Betrug) and crime (Verbrechen; $\S 83$ ). In the first, distinctive of private law, the person is not against the law in itself, but his own will be thought to do what is according to law; the author gives as an example the case that two people go to court because of the ownership of a plot of land, since both really believe they are owners $(\S \S 84-86)$.

Fraud means a particular will against the law, but making the other part believe that his particular will is in accordance with the general will.

Finally, crime constitutes a particular will which attacks the general will and the particular will of the other individual, and it is the genuine unlawfulness ( $\S 90 \mathrm{ff}$; especially $\S 95$ ); consequently, it seems that only the intentional act belongs to the field of criminal law, and that it is understood by many of the Hegelian criminal lawyers.

In 1867, Merkel (1836-1896), with the intention of fixing what he considers as unlawful, analyzes Hegel's conception, and repeals it: "When we set up private unlawfulness against the criminal one, we should not think of a grading of unlawful behaviors - since a lot of legal infringements, as, for instance, the majority of patrimonial damages appear both as criminal and private unlawfulness-but in a distinction of the legal consequences of the unlawfulness, that is to say, in different aspects of legal liability that can be founded in unlawful behavior".

According to his judgment, any unlawfulness contains two aspects: a) a breach of the general will, made objective by the law; b) the imputability. "Law can be defined as a set of legal commands and prohibitions; unlawfulness, thus, as the breach of such orders and prohibitions. But these commands are directed at the will of an imputable human being... Hence, the infringement of law is due to an offender's infringement of his duty. But there are only duties for imputable human beings and they are measured according to theirs capacities. There is no duty to fulfill what is impossible for the human being, or to prevent and avoid what is unavoidable. Consequently, there can be no legal infringement in not preventing and not avoiding".

Obviously, the action of a non-imputable person damages goods protected by law, but its valuation has to be exactly the same as that of natural events; otherwise, "we should also consider wind and storm as acting beings of unlawfulness". Notwithstanding, the previous considerations do not imply that we cannot turn to self-defense or other actions for the maintenance of situations according to law (e.g., the owner against the possessor in good faith), because resorting to these actions does not depend on the other party's fault [2].

Some months later in that year, Jhering (1812-1892) answered Merkel's observations with a little work called Das Schuldmoment im römischen Privatrecht (The Moment of Fault in Roman Private Law): "Anyone feels the difference between the possessor in good faith's claim of his own thing and that of the robbed person against the thief. In the former case, we deal just with the existence of the debated right, and the defendant does not need the blame of a legal infringement, conscious and faulty... in other words, the moment of the subjective fault is irrelevant for this claim, which has simply as object the failure of correspondence to law of the defendant's certain personal situation. On the contrary, the claim against the thief relies basically on the blame of his legal offence, e.g., conscious and voluntary breach of our right; the subjective fault's moment is essential here, there is 
no theft without intention. In both cases we are dealing with the fulfillment of the plaintiff's right; therefore, the Court's decision which recognizes and restores it puts an end to an unlawfulness in the offender and, to my eye, there is no justified doubt that in both cases one can speak of an unlawfulness (Unrecht), to which the expression objective unlawfulness is recommendable in one case and subjective unlawfulness in the other [3]".

The debate continues today, although German criminal law scholars are almost unanimous that unlawfulness refers to the conduct [4]. In contrast, tort law scholarship is divided, but most hold the opinion that unlawfulness is related to the damage and the result, for unlawfulness of the conduct is not according to the $\S 823$ 's wording, since that point of view includes negligence in unlawfulness (§ 823: "Whoever causes damage either intentionally or negligently in an unlawful way to another person's life, body, health, freedom, property or any other special right, has to compensate for the damage"). Besides, it reduces the potential damaged person's possibilities of defense: in the face of a diligent conduct, it will be impossible neither self-defense nor a claim of omission (Unterlassungsanspruch). When the owner can demand the omission of a conduct or the removal of certain situation, the result of the conduct and the situation is always unlawful [5].

\section{The Origin and Development of the Concept of Unlawfulness}

\subsection{Roman Law}

To decide the above question, it may be important to have some overview of the history of the term unlawfulness. As mentioned before, the notion was created by German speaking scholars, but its roots are in Roman Law; to be precise, in the Roman Lex Aquilia de damno (about the beginning of the 3rd century BC; it was, actually, a plebiscitum and not a lex). It was later collected in the so-called Corpus Iuris Civilis, in particular, in three places: Institutiones 4.3, Digesta 9.2 and Codex 3.35 (formula in D. 9.2.27.5). Inst. 4.3 started by stating "Damni iniuriae actio constituitur per legem Aquiliam" ("the action for damages coming from unlawfulness was created by the Lex Aquilia"), and the 12th paragraph of the Lex, the most important for the practice of the Modern Age, for it regulated damage in general, required a damnun iniuria datum, i.e. a damage caused with iniuria (see also, the same expression verbatim, D. 9.2.11.7; eod. 17; and especially eod. 49.1).

Iniuria (etymological origin of the English word "injury") meant literally "unjust" or "against the law", being ius-iuris "law", and "in" a negative prefix of Proto Indo-European origin. Yet, that meaning had many nuances which, besides, changed with the evolution of the Roman language and law [6]. It is impossible here to handle the manifold discussions about the issue and the different opinions. Therefore, based on the argument from authority of its supporters, I back up the interpretation of those who think that, in the very beginning, the insertion of iniuria was to make clear that a damage was only to be redressed when caused on purpose (dolus malus, evil intent); only over the years did the expression come to include negligence or culpa [7].

So, the act of the defendant was in accordance with the law when there was any ground of justification, especially, self-defense; as a matter of fact, Inst., eod., 2 says that "Iniuria autem occidere intellegitur, qui nullo iure occidit. itaque qui latronem occidit, non tenetur, utique si aliter periculum effugere non potest" ("it is also understood as unlawfulness murdering by one who murders without right; therefore, the one who murders a thief is not liable when he cannot escape from the danger in any way"; see also, among many other places, D. 1.1.3; D. 4.2.12.1).

Yet, it is difficult to accept that the requirement of evil intent was included with precisely the grounds of justification in mind, for these have no special chapter in the Corpus Iuris Civilis, a highly elaborated work, with great influence from the Berito's (today, Beirut) school, which made a much more abstract approach to Roman law. Even in this work, the grounds of justification are scattered here, there and everywhere.

\subsection{The Ius Commune Tradition and Its Corollary, the French Code}

Whatever the meaning of iniuria in Roman law, legal writers of the so-called Ius Commune did not concern themselves with iniuria in the Lex Aquilia. Once negligence was included among the elements of aquilian liability, iniuria, the evil intent, lost interest for lawyers [8]. Thus, in Bartolus' (1313-1357) commentaries on the subject, the word iniuria seldom appears, and there is no general treatment of the concept [9].

JacobusCujacius (Jacques Cujas), two centuries later (1520-1590), while studying the Lex Aquilia according to the so-called mos gallicus, linked the concept iniuria with culpa, i.e. either intent or negligence: "In ea lege iniuria significat culpa" ("in that statute, unlawfulness means fault") [10]. 
From the Modern Age onwards, private law in general, that is to say, Roman law, began to split and to go its own way in each country. Nevertheless, most of the western continental private laws followed in the wake of France. Jean Domat (1625-1696) and Robert Pothier (1699-1772) [11], the most egregious jurists of that country, considered three elements were necessary to successfully sue an action in tort: a) damage (damnum), b) either intention (dolus, délict) or negligence (culpa, quasi-délict) and c) a relationship of causation, although this element was almost unstressed. It is important to make clear that the expression culpa was used in three different senses: a) as negligence; b) as intention and negligence together; c) or, finally, to refer to the blamelessness of mentally ill persons and minors.

To conclude: The concept of iniuria was completely irrelevant. Intent and negligence were enough by far.

\subsection{Modern Age, Rational Natural Law and Usus Modernus Pandectarum}

For many years scholars of the German speaking area followed the teaching of the Ius Commune. But with the Dutchman Hugo Grotius (Huigh de Groot, 1583-1645) and the German Samuel von Pufendorf (1632-1694) a new era in continental philosophy of law began. Grotius's foundation of natural law solely in human reason, either God exists or not or does not care about human problems [12], was the starting point of rationalism in law. The success of his work was, the Netherlands apart, exceptional in the German-speaking areas (as a matter of fact, he lived for some time in Germany). And, for these authors, almost all law can be deduced from certain rational axioms.

Applying those ideas to the issue in question, from the principle that an act can be against the law the whole problem of its criminal and tort law effects could be inferred.

Grotius mentions the word iniuria several times in his already cited major work, but does not address the issue. Notwithstanding, in his Introduction to the Law of Holland he devotes some pages to the sources of obligation and includes crime among them. From his point of view "Crime is a doing or letting a state of affairs remain as it was, when not allowed by its own nature or any statute [13]", and "From crime can arise two obligations: on the one hand, the punishment; on the other, the redress of the damage". From these lines it has been affirmed by Dutch scholarship that Grotius already had in mind the concept of unlawfulness, which was supposedly borrowed by Domat and later by Pothier [14].

In any case, the first author for centuries to devote some lines to the word iniuria was Pufendorf in his work Elementorum jurisprudentiae universalis libri duo (first edition, 1660) [15]. In I, XVII, VI he asks himself "Iniuria quid propie?" ("What is properly unlawfulness?"), and answers in the next paragraph (VII) that "Ad injuriam quoque propie dictam requiritur, ut ex proeaeresi ea processerit"; that is to say, "Speaking properly of unlawfulness also requires that it comes from a free moral choice". So, it is not unlawful to cause an injury through an act of God, with the author adding some examples, and finally making the traditional distinction of the Ius Commune between gross, light and extremely light fault (culpa lata, levis and levissima).

Many others philosophers of law pertaining to the rationalist school followed in the wake of Pufendorf. Noteworthy among them is Christian Thomasius (1655-1728), who also affirmed that "Unlawfulness is the opposite of law and obligation, because who uses his own right does no wrong to anyone. And from unlawfulness, i.e. refusal of law when someone was bound to act otherwise, arises an unlawful act against a fair obligation [16]".

The next and last noteworthy philosopher of law to be mentioned here is Christian Wolff (1679-1754), according to whom "It is called unlawfulness the violation of another's perfect right, from which it is plainly clear that unlawfulness is forbidden and naturally against the law", and in the next paragraph adds that "Damaging another is either breaching his perfect right or causing him an unlawful act; therefore, each injury means unlawfulness [17]" (sic).

In other respects, scholars of the German-speaking area started to explain positive law on a different basis and method, with the emergence of the so-called Usus Modernus Pandectarum ("Modern Use of Pandectas"), whose main characteristic was "the overcoming of the so-called 'theoretical Reception' (of Ius Commune), which held the conviction that Roman law had general validity in the Empire of the Middle Ages as a consequence of the translation imperii" [18] (transfer of authority from Roman Empire to the Holy Roman Empire, ruled by the Germans). Now the only sources of correct law were human reason and the power of the emperor [19].

However, it is easily observed that both philosophers of law and writers on valid law, although appealing to 
natural reason, took the concept of unlawfulness from the texts of Roman law. The rational law texts mentioned here are full of quotations from Roman law, with which these authors were highly familiar, although they commonly do not mention the source. Thus, for instance, in the field of tort, Thomasius wrote a small work called Larva legis aquiliae, detracta actioni de damno dato.

This can be confirmed from a superficial glance on the scholars who dealt with tort and criminal law. Their expositions were based, on the one hand, on the new philosophy of law, so that, little by little, the requisite of iniuria was essential to define crime and tort; and, on the other hand, on the texts of Roman law.

It is impossible in these few lines to deal with this evolution in detail. Therefore, a quick overview of some of the most important authors will be made, especially those who show the evolution most clearly. Furthermore, it must be taken into account that sometimes criminal and tortious aspects of an action were handled together, since in Roman law damage was a private crime, and those legislations and authors required a previous statute to consider an act as criminal.

As mentioned, the starting point was the teachings of the Ius Commune. So, before the new ideas became widespread, Wolfgang A. Lauterbach (1618-1678) asserted, under the heading De Privatis Delictis, that "Delictum (a word which here includes tort and crime) is an event voluntarily admitted against honesty and law... It requires (1) an event... (2) that is voluntarily admitted, i.e. either intentional or negligent; the act of God is excluded [20]". Nevertheless, in his major work, Collegium theoretico-practicum ad quinquaginta Pandectarum libros while handling the concept of iniuria, he explained it thereafter by putting the words "intention" and "negligence" between brackets [21].

But soon criminal and tort law authors included unlawfulness as a different requisite for an action in tort or crime. Let us see a couple of examples. Georg A. Struve (1619-1692) wrote "Delictum in general is an event unlawful in itself (in se illicitum) committed voluntarily against a prohibiting statute [22]". For Johann G. Heineccius (1681-1741), "Actually, damage caused unlawfully is any decrease of assets made by a free man without any right to do so" [23].

Among the experts in criminal law stands out Johann S. F. von Böhmer (1702-1772), according to whom "Crimes are any actions or omissions against the law, voluntary admitted [24]".

When German speaking authors started to write in their mother tongue, they translated the word iniuria either as Unrecht (unlaw) or as Rechtswidrigkeit or as Widerrechtlichkeit (unlawfulness), although the second is the more used in legal language nowadays. At the end of this process, the last author of the Usus modernus Pandectarum, Christian F. Glück (1755-1831) wrote that "Damage can be brought about by a right-minded person through unlawful (widerrechtlich) harm to another's thing. Such unlawful (rechtswidrig) damage... is called damnum iniuria datum [25]".

Among the legislations, the Austrian Constitutio Criminalis Theresiana, from 1768, statute influenced by Johann S. F. von Böhmer [26], laid out in art 1, 1 That "Crime is doing or not doing something against the law..." (gesetzwidrig); and its art 81,1 required that in case of self-defense (Notwehr) the attack was against the law (widerrechtlich); the official edition of the Constitutio contained marginal notes in Latin, and, meaningfully, translated the Latin injuste by widerrechtlich ("unlawfully") [27]. And the Prusian Allgemeines Landrecht, from 1794, stated: "The person who unlawfully (widerrechtlich) causes damage to any one through an intentional conduct, commits a crime".

As to tort law, the same Allgemeines Landrecht (1.Theil, 6.Titel, § 16) considered that "Damage coming from a conduct must be compensated only when the conduct infringes a prohibitive statute; or when the one who acts has placed himself, through an illegal (gesetzwidrig) behavior, in the circumstances which have accounted for the conduct". Likewise, Zweyter Theil, 20. Titel, §517 laid down that "Anyone has the right to avert the danger of an unlawful (unrechtsmässig) damage that threatens him, his family or his neighbors, using means appropriate to the situation".

\subsection{The 19th Century and the Enactment of the German Civil Code}

Therefore, at the beginning of the 19th century the requirement of unlawfulness for an action in tort and the use of the noun Rechtswidrigkeit or Widerrechtlichkeit (and the adjectives rechtswidrig and widerrechtlich) was very widespread among scholars and legislations of the German speaking area. This use was due in some cases to the necessity to refer to the grounds which justify an apparent unlawful act (self-defense, necessity, etc), or just for the sake of it, because it was a philosophical requirement. But saying that something is unlawful is a 
purely formal statement-not according to the law-which requires a material content, and that was exactly its main flaw [28].

As advanced before, from the late 18th century onward German criminal scholars were of special relevance in the development of the term unlawfulness. Their handling of the problem of self-defense, based on the Ius Commune's commentaries, demanded that the attack which justified the defense had to be unlawful, an "unjust" aggressio or offensio [29]; the reason was to explain that self-defense against justified attacks of the police, or against a landowner who repelled a trespasser on his land was not possible.

Criminal law authors tried throughout the 19th century to structure crime according to the principles of rationalism and positivism. This systematic study meant that by the middle of the century the elements of crime were clearly established: action (including causation, which was by now well studied), unlawfulness and fault (the latter in a very broad sense, which included intentionality, negligence and the so-called grounds of excuse, like childhood and mental illness) [30], though contemporary authors usually consider the criminal law expert Franz von Liszt (1851-1919) to be the greatest exponent of this trend [31]. The crime had, then, an objective part- the fact itself-and a subjective one - the intention or negligence of the author. As stated before, current scholarship normally explains this division because of the positivism of that age and the desire to follow the experimental sciences method. Notwithstanding, not everything can be explained by that, since it is a first intuitive impression in every one of us. Ius Commune criminal authors already distinguished between imputation facti and imputatio iuris [32], and Common Law still distinguishes between actus reus—objective aspect-and mens rea — subjective aspect.

Anyway, as to the issue dealt with here, the study of self-defense and other circumstances which justified the apparent criminal conduct, led criminal scholars to deem that the function of the unlawfulness judgment was to accept a group of circumstances that justified the apparently criminal action, and this still holds the vast majority. To these elements Ernst von Beling [33] added typicity (the objective element of the crime: Tatbestandmässigkeit; in some way similar to actus reus).

From the civil point of view, the evolution ended up for the time being with the enactment of the German Civil Code. Its $\S \S 226$ to 228 regulate thoroughly self-defense, state of necessity and self-help (Selbsthilfe). Selfdefense requires that the attack is unlawful (rechtswidrig).

As to tort law, $\S 823.1$ sets out that "Whoever causes damage either intentionally or negligently in a unlawful way to another person's life, body, health, freedom, property or any other special right, has to compensate for the damage". From our point of view, as mentioned earlier, the reason for the incorporation of the word "unlawful" was purely traditional and philosophical [34].

\subsection{The Current Situation in Other European Jurisdictions}

\subsubsection{General}

As it has been stated above, the concept of unlawfulness in tort law is a problem sparked off by German speaking scholars, and widespread by the German Civil Code (BGB). The huge influence of this Code has meant that the Civil Codes of other jurisdictions of Western Europe have included this requisite in the action for tort. The element of unlawfulness is incorporated-in order of enactment-in the Italian (art 2043), Portuguese (art 483.1) and Dutch (BW, art 6:162) Civil Codes (CC). Notwithstanding, there were Civil Codes in the German speaking area which had made reference to unlawfulness prior to the German one. The Swiss Obligationenrecht (OR) from 1881 (which came into force in 1883) already contained an allusion to unlawfulness in art 50, and the Austrian Civil Code (ABGB) from 1811 also refers to unlawfulness in $\S 1295$, although $\S 1296$, the central element in this sphere, refers only to fault (Verschulden), the translation of the Latin culpa. However, the influence on the continental area led by France, comes from the German Civil Code, which is the culmination of the Pandectistic.

Other Civil Codes (French, Belgian, Luxembourger and Spanish) do not envisage this element, although in some of these countries the issue is an object of debate, while in Common Law the concept is almost completely unknown, except, perhaps, by the way of the grounds of justification .

In the case of some very well known European Projects of a European Civil Code, or at least of a unified tort law, the Common Frame of Reference does not consider unlawfulness as an element of any tort on the grounds that there is no consensus on what this term means, even in those countries whose Civil Code recognizes this requirement [35]. In contrast, the Principles of European Tort Law mentions unlawfulness under the subject of 
self-defense (art 7:101).

As to the problem we are dealing here with -unlawfulness of conduct or damage-, the opinions of scholars and Courts of different jurisdictions are manifold. They follow the German pattern only to a certain degree.

Starting with the countries whose Civil Codes require unlawfulness, but whose drafters did not address the problem, in Austria the point of view of the most important scholar in this field is that unlawfulness refers to the conduct, because "unlawfulness means nothing but the appraisal that there is an infringement of a norm. And only human beings can act against legal norms, since they are exclusively the addresses of norms" [36].

In Switzerland the prevailing attitude seems to be that unlawfulness refers to the damage, although the topic is pretty much discussed and the conclusions a little confusing [37]. So, for example, the Federal Supreme Court has stated that "Therefore, causation of damage is unlawful when it infringes a legal duty because either an absolute right is violated (unlawfulness of the result) or a purely economic damage is provoked through a violation of a particular norm of protection (unlawfulness of conduct). Unlawfulness means an objective violation of a norm, and is missing when there is a ground of justification" (23 November 1990, BGE $116 \mathrm{Ib}$ 367; similar, 18 March 1993 BGE 119 II 127).

In the Netherlands, the last country in Western Europe to include the need for unlawfulness, the topic was directly addressed before the enactment of sixth book of the Civil Code, and the general estimation is that "Only improper conduct is illegal and can lead to liability under art 6:162" [38], emphasizing that the opposite opinion "would lead to the absurdity that all injuries and property damages were unlawful [39]".

In contrast, in Portugal, without any doubt, the term unlawfully (ilicitamente) was included thinking about the result, since the legislator intended to protect only certain rights through tort law [40]. But part of the current scholarship has shifted its meaning to the tortfeasor's behavior, based on the reason that "if the agent acted according to the rules of traffic it seems incorrect to consider as present the unlawfulness (even in the case that there is no ground of justification), simply because that behavior led to the result, as in the example of the driver of a train who, driving correctly, kills a suicide who has put himself on the railway" [41].

Taking a completely different perspective, the drafters of the Italian Codice Civile, when writing art 2043, which requires an "unlawful" damage, were thinking of the grounds of justification; this is plainly clear from a reading of the Relazione del Guardasigilli (Minister of Justice's explanation) [42]. However, the unlawfulness issue has nowadays moved on in Italy to the problem of what kind of damages can trigger liability [43].

\subsubsection{The Special Case of Spain}

Taking into account that the author of this paper is a Spaniard, Spanish law will be dealt with here with a little further detail.

Spain is probably the sole country in Western Europe where the requisite of unlawfulness is debated, although it does not appear in its Civil Code (art 1902, which is, more or less, a copy of the French one: "Whoever, by act or omission, causes damage to another through fault or negligence is bound to make good the caused damage"). Even so, the debate is not naturally as deep as in the countries whose legislations do include that element.

The origin of the import lies in criminal law scholarship, which by the beginning of the 20th century had started to speak of unlawfulness as a requisite of crime, influenced by German speaking scholars, and spread to a large extent through Italians. The term chosen was a neologism, again through Italians: antijuridicidad, which took the place of the traditional word ilicitud, the latter coming from Latin, and used in the rest of the Romanic languages.

The new word soon grew in tort law, and was used in legal books to refer to the grounds of justification. For decades the situation remained unchanged, with some exceptions [44].

An important moment in the development of the issue was an outstanding comment on art $1902 \mathrm{CC}$ included in a major work [45]. Scholars and courts have ever since paid more attention to the subject. The opinions among legal authors range from those who reject such requirement to those who accept it with half-way theses. Those who reject it hold the opinion that there is no limitation in our law as to the kind of damages to be redressed and that we already have the word culpa (fault) to refer to all the situations pretended by the new word and do not need any further element [46].

In contrast, a large number accept this element and they usually think that unlawfulness refers to the damage. The grounds are disparate, but the main ones are:

-It is in accordance with the historical precedents. As early as the Lex Aquilia, law demanded a damnum iniuria datum. 
-The literal sense of art 1089 CC (included among the sources of obligations, not in tort law), which states that "Obligations arise out of unlawful acts and omissions in which intervene any kind of fault or negligence".

-Unlawfulness is just the factor which bounds the field of redressable damages. The answer to why a pedestrian has no action for environmental damage lies in the fact that his damaged interest is not legally protected and, therefore, since those damages have not caused the pedestrian the quality of unlawfulness, they are not compensable, unlike, e.g. the owner of a building whose façade has been stained by pollution from a factory.

-The existence of lawful damages in our law, which bring about an effect different from civil liability. Thus, it especially happens with the grounds which exclude unlawfulness, like self-defense [47].

The main half-way thesis holds the idea that it is possible to speak of judgment of unlawfulness if culpa or fault is embodied in that concept. That is to say, if we consider that unlawfulness and fault are one and the same thing [48].

In case law Civil Courts use the term "unlawfulness" now and again (e.g., 26 December 2014, RJ 2014\6902; 3 September 2014, RJ 2014\4944; 14 October 2008, RJ 2008\6913; 9 October 2008, RJ 200816042; 5 May 2008, RJ 200812947-self-defense; etc.), especially in cases where the defendant has complied with administrative regulations on security, which the Court considers insufficient to avoid the qualification of the act as unlawful (e.g., 12 January 2010, RJ 2011 305: noise coming from a marble factory which affects the neighbors, even though the factory complied with the administrative provisions on noise; compare this with 18 February 2010, RJ 2010 1286) [49]. In any case, the Supreme Court does not overstress the relevance of this element, it does not clarify the difference between culpa (fault) and antijuridicidad (unlawfulness), and sometimes even insinuates that the latter is not an element of any tort (e.g., 9 March 2010, RJ 201013787; 11 July 2002 RJ 200218247).

As to Public Administration's torts, scholarship and courts, influenced by Italian authors, agree that "unlawfulness" refers to the damage. The reason is that our law sets up strict liability of Public Administration, so that any damage caused by it is against the law, because "the citizen has no legal duty to bear it" (i.e. the damage) [50]. Therefore, Administrative Courts, which are competent to deal with lawsuits for torts of the Public Administration, frequently use the term "unlawfulness" or "unlawful" to refer to damage (e.g., 27 April 2015 RJ 2015\1212; 23 March 2015, RJ 2015\1321; 16 March 2015, RJ 2015\1137; 9 March 2015, RJ 2015\1106, etc.).

After this overview, the question which arises immediately is: do we need a requisite which appears only in some jurisdictions when Courts decisions all over Europe are to a great extent the same?

\section{Unlawfulness of Conduct or Outcome.}

\subsection{Criticism of the Doctrine of Unlawfulness of Result}

In the jurisdictions where there are only certain types of damages protected by tort law, it can be said that unlawfulness concerns the result, the damage. At the same time, if the conduct is against the law, it can be said that it is unlawful (e.g., the attempt of crime is unlawful). Therefore, the question is in some way purely terminological.

Here appears the key of the critic of Jhering's doctrine. This author made use of the same word (fault, Schuld) to refer to two different sources of an obligation (enrichment, damage), which have different premises. The relevance of the person's behavior in the case of the use of another's thing and in the case of the destruction of another's thing is completely different. The obligation to return the possession does not depend on a valuation of the conduct, unlike the obligation to redress the damage.

Anyway, it is better to limit the term unlawfulness to the conduct for the following reasons:

+If unlawfulness is referred to the damage, it should be considered as unlawful damage caused by a hailstorm, a dog or a bear, which contradicts the normal way of speaking and the common social values. Law rules human behavior.

+In case that unlawfulness means the same as damage (or especially protected damages), the requisite is fully redundant.

+ There is a great contradiction in the authors who defend that unlawfulness refers to the result when they accept the grounds of justification as defenses against the unlawfulness of the result. If the damage is unlawful, it does not matter whether the actor behaved correctly; the unlawfulness of the result remains anyway.

Therefore, if the rejected point of view was consistent, it should consider the death of a human being in selfdefense as unlawful, for if the unlawfulness relates to the damage, the fact that the actor acted in self-defense does not exclude the disvalue of the result (i.e. the death of a human being). 
Even more, if there is no unlawfulness until the damage has been brought about, an assaulted person may not defend himself or carry out any of the justifying conducts until the damage has appeared [51].

+In contrast to the opinion that it is a nonsense that the proprietor of a land cannot repel the disturbance of a trespasser, and at the same time the trespasser has the right to tread on the other's land, it can be alleged that: the fact that someone is proprietor of a land, and that he has in principle the right to repel any disturbance, does not mean that his right is so absolute that it cannot be subjected to a balance of values, for no right is absolute, not even life.

For example, if a robber hunts down a peaceful pedestrian and the latter has no way out than to tread on the flowers that the garden's proprietor so carefully looks after, we are before a state of necessity and the trespasser does not have to redress the damage, since there is no unlawfulness in his conduct and he is trying to save his life, not his assets.

Let us now imagine that someone is convinced with good reasons that a certain strip of land of her plot is hers, and the neighbor thinks exactly the opposite. Probably, both are acting lawfully when treading on the controversial plot of land.

In the end, herein lies a profound matter of philosophy of law. Legal rules try to make social life as frictionless as possible, but there are cases in which it is impossible, even from a theoretical point of view, to avert those frictions. Social life relates to human behavior, and this, in turn, relates to the person who acts.

Expressed in a slightly simplified way, it can be said that tort law presupposes that each citizen enjoys a sphere of freedom in which to act. A good part of scholarship seems to have the presupposition that peoples' sphere of freedom are tangent circles and, consequently, from this premise it is logical to think that the one who interferes in another's field of action, so bringing him damage, has to undo it, as general rule.

But that is not completely true. Due to our life in community and to the limited human being's capacities, the relationships between citizens presuppose that the freedom spheres are in a Venn relationship.

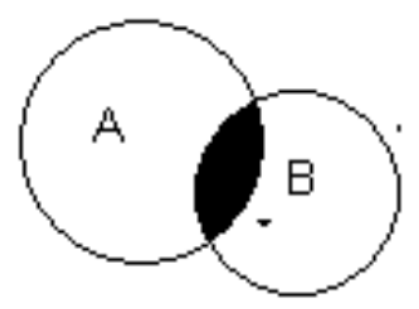

No matter how much we may wish the contrary in an ideal world, human beings' action spheres are constantly in conflict. When we analyze, e.g., A's conduct, what we check out is whether A has remained in his freedom circle, granted by law. Only when A gets out of his sphere and harms B does tort law appear. And that is precisely the commutative justice which underlies tort law: whoever surpasses his or her sphere of action must undo the damage caused.

In contrast, if A does not surpass his action circle and, notwithstanding, causes harm to B (confluence zone), there is no reason to impose any liability on him. Commutative justice does not mean that anyone who harms another has to compensate, because that leads to artificially shifting damage from one's patrimony to another's. As stated by one prestigious scholar, "Society has no interest in the mere shifting of loss between individuals for its own sake. The loss, by hypothesis, has already occurred" [52].

A different issue is whether $\mathrm{B}$, in the confluence zone, which is also in her activities' circle, can defend herself against the foreseeable damage coming from A. In my opinion, yes (as in the famous problem of the plank of Carneades).

+And there is still a third question which appears frequently in the jurisdictions where there are not limit as to the damages to be compensated. According to many scholars and courts' decisions there is a supposed rule in the field or torts: alterum non laedere (D 1.10.10.1; "you cannot cause damage to others"). But against this can be cited the saying qui iure suo utitur, neminem laedit ("whoever uses his right, harms nobody"), Latin as well. It can be easily observed that human beings steadily harm one another, and it has no legal consequence. Let us see some examples: If one sets up a bar right opposite an existing one, it is possible that the latter's profits will decrease, but that damage is not to be compensated, for we live in market economy; if someone is in the queue waiting to get a ticket for a theatre play, and the one just before him buys the last ticket, he cannot make anyone 
liable for that; neither do we compensate the harm suffered by a student who fails an exam although the teacher acted on purpose; nor that endured by the prisoner in jail according to a right judicial decision; nor that borne because my son takes drugs or marries someone I dislike; and so on.

In short, the basic rule since the Roman law is casum sentit dominus (see D. 19.2.15; "the owner bears the damage"). To impose liability on someone a special justification is necessary.

\subsection{Doctrine of the Unlawfulness of Conduct}

\subsubsection{General Remarks}

Once rejected that unlawfulness does not refer to the outcome, let us consider the doctrine which thinks that it is referred to the conduct.

As a consequence of the legal positivism and the inferiority complex of legal scholars to experimental sciences, the legal norm is frequently seen as a purely logical procedure, that is, the conditional or hypothetical syllogism: Given a universal norm and a particular case, if the case can be included in the universal norm, the consequence of the universal norm must be applied.

In logical terms:

1. A $\rightarrow$ B (major premise).

2. A (minor premise)

3. B (conclusion).

$[" \rightarrow$ " $=$ if...then]

In the field of torts:

1. If someone causes damage to another through an incorrect conduct (A), he is liable to compensate the damage (B).

2. Tom has caused damage to Dick through an incorrect conduct (a).

3. Tom is liable to compensate Dick (b).

Notwithstanding, things are not that easy, because, as many authors have put forward, there is no certainty on the premises of this supposed syllogism. This is what it is called enthymeme in logic; its role is not the demonstration, but giving probable arguments. That is why that it can be said that "The practice of law is not the discovery of truth; it is the art of persuasion" [53]; "legal reasoning entails a practice of argumentation. The reasons given for the conclusions reached are to be measured by their persuasiveness, not by reference to some established true state of affairs" [54].

From my point of view, fixing what is lawful or not in the law of torts is eventually a question of balancing values. In any harmful event, there are at least two competing values: the freedom of the acting person, on the one hand, and the legal protected right or good which has been damaged, on the other hand.

When it is said that the wrongdoer has not behaved carefully, we are, deep down, comparing the relevance of the damaged right and the degree of restriction or control of his freedom, which the tortfeasor should have exercised. As a good example, balance of values steadily appears in Court resolutions all over Europe on the topic of conflicts between freedom of expression and right of privacy.

Consequently, it has been said by a very recognized author that "The Subsumption Formula is represented by a scheme that works according to the rules of logic, the Weight Formula, by a scheme that works according to the rules of arithmetic" [55]. However, that statement does not solve all problems, for trying to clear up any weighting conflict means "that all the values to be considered as an object of a moral duty can be sorted out-as a thermometer's marks-like a unitary scale" [56], and it is exactly that, which is quite debatable.

Indeed, one of the problems of current ethics is that of incommensurability, which deep down is applicable to the topic we are dealing with.

\subsubsection{Negligence and Intentionality as Forms of Unlawfulness}

1) Negligence.

Let us start with negligence. Defining negligence is almost impossible, apart from what has already been stated.

What it is interesting here is not the study of all its problems and nuances, but the role which it plays in the structure of tort law. From this point of view, the only characteristic of the aforementioned balance is that in this case there is no intentionality in the actor. That is, let "A", "B", "C" and "I" be the values or factors to consider 
the correctness or incorrectness of a conduct, and let "I" be intentionality, there is a problem of negligence when there is no "I" in the given case.

In logical terms: $\mathrm{N} \rightarrow \mathrm{A} \Lambda \mathrm{B} \Lambda \mathrm{C} \neg \mathrm{I}$

$[" \mathrm{~N}$ " = negligence; “ $\rightarrow$ " = if... then; " $\Lambda$ " = and; " $\neg "=$ no]

Accordingly, it has been said that "negligence is not a state of mind, but a conduct that falls below the standard regarded as normal or desirable" [57].

2) Intentionality.

The inclusion of intentionality as an element of the unlawfulness of the conduct in Germany is due, above all, to criminal law scholars, especially to the so called "final behavior doctrine" (finale Handlungslehre), whose founder was the criminal law expert Hans Welzel (1904-77) [58]. Although this doctrine is nowadays rejected even among German criminal law scholars, the idea that intentionality can be a basic factor in the assessment of the unlawfulness of the conduct is generally accepted.

And, as a consequence, many criminal authors, German or not, have ended up considering that negligence has to be as well a form of the unlawfulness of the criminal act. So, negligence and intentionality are not to do now with fault in the subjective sense.

In contrast, tort law authors have not concerned themselves too much with intentionality, because they seem to deem implicitly that what is to be compensated is the damage, and that the function of tort law is not to punish. From this standpoint it would be the same whether the damage occurred intentionally or negligently.

However, the purpose of causing damage may have huge relevance in a variety of cases; and this "discovery" can be considered as the main achievement of the German doctrine of the final behavior. Let us meditate on some groups of cases:

+ It is not necessary to infringe the norm of negligent conduct to be held liable. For instance, in Spain you cannot drive in build-up areas over $50 \mathrm{~km} / \mathrm{h}$. Let us imagine that you drive your car at a speed of, say, $40 \mathrm{~km} / \mathrm{h}$ and you see a pedestrian crossing the street at a forbidden place (e.g. away from a pedestrian crossing); so, you decide not to stop and eventually knock him down: we are before an unlawful conduct.

Here appears in all its strength what some criminal law authors call "assessment norm" (Bewertungsnorm); since the law tries to protect certain goods, the will of damaging them may lead to liability, no matter what means the wrongdoer uses.

+It may widen the scope of the protected goods or rights, goods which would not be protected in an instance of negligence.

-For example, under Spanish law the breach of an engagement of marriage does not lead to an action in tort for psychological damage (art $42 \mathrm{CC}$ ), but it would probably be different if the intention of the promise was just to deceive the promisee, because of, say, a bet with a friend.

-The will of harming can likewise explain a lot of cases of the French doctrine (accepted in other jurisdictions) of the abuse de droit. So, when you construct a fake high chimney with the only intention of disturbing the view of the neighbor (famous case before the Courd'Appel Colmar, 2 May 1855, Recuil Dalloz Periodique et Critique, 1856-II, 9). It is also very well known in Germany a decision of the Amtsgericht of Münster (Neue Juristische Wochenschrift, 1983, 2886) in which the Court accepted the so-called negative action against a neighbor who had put little stones, a rubbish skip and two buckets on the edge of his property, so impeding his own view of the scrap with a little wall, but leaving the view open to his neighbor.

-Some cases of the so called interference with contractual relations. Of course, this can be only a ground for compensation if the one who interferes acts in the knowledge of that contractual relation.

+Even on the topic of liability of parents for acts of their children, it is commonly said that if the parents are liable when the minor acts negligently, all the more so when the damage is caused on purpose. Yet, everyone is aware of the fact that it is not the same to control a naughty boy as a serial killer, even if he is under 18. Spanish Courts are quite strict with the responsibility of parents, but as an exception acquitted them in a case in which the minor-a 17 year-old-committed a rape (STS 2 March 1994, RJ 2097).

In short, as we have already seen, the way of deciding whether a conduct is unlawful is a balance of values, and the will to cause the harm is another factor (following the aforementioned example: "I") to take into account. The function of this factor is neither to increase the measure of damage nor the compensation nor to punish the tortfeasor, but to make unlawful an act that otherwise would not be wrongful.

Therefore, whoever has special knowledge or skill, for whatever reason, must behave according to those skills, that is, better than the human being considered as the standard. For example, if the life-guard of a swimming 
pool sees someone drowning, it is not enough for him to swim as fast as the standard guard; he has to use all his skills [59]. Why? Here again arises the valuation norm; that conscious contempt of another person's life is not tolerated by either criminal law or tort law. The same could be said of the surgeon who knows very special techniques.

And now we have one important conclusion: unlawfulness refers not only to a conduct, but to a state of mind too. The proposed dichotomy of the unlawfulness between external conduct and state of mind is false; it can be one, the other or both at the same time. Unlawfulness is certainly a very complex concept.

3) Defenses or grounds of justification.

In all jurisdictions, both in criminal and tort law, authors collect a number of reasons that avoid the unlawfulness of an apparently wrongful act. Some times (especially in the area of Common Law) the list is quite miscellaneous [60], including all kinds of possible defenses; in contrast, in other countries a distinction is made between grounds of justification and grounds of excuse.

In this subsection I will only deal with those defenses which bar the qualification of wrongful of an intentional act. It is common here to mention self-defense, state of necessity, mistake, consent, certain acts of public authorities, and so on.

Legal authors tend to consider that a harmful act is unlawful, except when there is a defense. And the burden of proof lies with the defendant [61] Thus, defense is the exception which proves the rule that a voluntary damage implies a tort.

This way of thinking is not convincing at all. First of all, we have to distinguish between substantive and procedural law. The burden of proof is a procedural rule which must be differentiated from the substantive assessment of whether an act is tortious or not.

But even in the procedural field, the statement that the burden of proof lies always with the defendant is dubious. Let us think, for instance, in the cases of assault and battery committed by the police in the exercise of their duties. From a statistical point of view, most of them are done according to the law, so it has been said with good reason that "It is clear that the burden of disproving claims of public or private defense rests on the prosecution" [62].

Furthermore, speaking of defenses implies a way of thinking which follows in the wake of the procedural law [63]. From the substantive point of view, the assessment of whether a conduct is unlawful must be made as a whole. Therefore, the sentence "Whoever murders someone intentionally acts unlawfully, except when there is any ground of justification" does not embrace any independent statement, but, deep down, merely repeats the premise; that is, to act unlawfully, it is necessary to act unlawfully.

Anyway, considering just substantive law, these defenses work in this way: let " $A$ ", "B" and "C" be the values or factors which make a conduct unlawful because of negligence. In a certain case one of these values is missing, but in turn the value "I" (intentionality) is present. We say then that the act is unlawful, except when there is any ground of justification, say, "J", "K" or " $\mathrm{L}$ ". But if we ponder the question carefully, we see that "J", " $\mathrm{K}$ " and " $\mathrm{L}$ " have relevance in order to consider the act unlawful if and only if "I" (intentionality) is present. Otherwise they are irrelevant. So, let "I", "J", "K" and "L" be a group of valuation, as "A", "B", "C" were as well a group of valuation, there is unlawfulness when there is intentionality and no defense in the given case.

In logical terms: $\mathrm{U} \rightarrow \mathrm{I} \neg \mathrm{J} \neg \mathrm{K} \neg \mathrm{L}$

[“U” = unlawfulness; “ $\rightarrow$ ” = if...then; “ $\neg ”=$ no]

For this reason the grounds of justification should be considered within the intentional act, and not as an independent requisite, applicable as much to intentionality as to negligence. In this regard, the current criminal law treatises which consider unlawfulness a completely different element of a crime whose only function is to examine whether there is any ground of justification must be considered incorrect.

The consequence from my point of view is that the grounds of justification are not a miscellaneous list, but only those elements of it which bar the intentionality of the conduct as an element of unlawfulness.

4) Partial conclusion.

Now the first clear conclusion of this paper can be drawn: There are two possible ways of evaluating whether an act is according or not to the law: negligence or intentionality (when all the elements of negligence are not present). And we need a concept which embodies the wrongfulness in both cases. This can be named fault, wrongfulness, incorrectness, unlawfulness or whatever we choose.

So in the end: $\mathrm{U} \rightarrow($ A B C) $\mathrm{V}(\mathrm{I} \neg \mathrm{J} \neg \mathrm{K} \neg \mathrm{L})$

$$
\text { ["U” = unlawfulness; } \rightarrow=\text { if...then;"V" = disjunction; “ } \neg "=\text { no] }
$$


On the other hand, the formula (A B C) $\Lambda$ (I $\neg \mathrm{J} \neg \mathrm{K} \neg \mathrm{L}$ ) [“ $\Lambda$ ” = and] is irrelevant because (A B C) are already enough to consider the action unlawful and intentionality does not add anything to the unlawfulness (for instance, shooting at someone in a crowded street), except in those countries were punitive damages are accepted.

\section{Fault or Blameworthiness}

In my opinion to make the defendant liable for a tortious conduct a further element is required, which is that he or she enjoys the necessary physical and psychical capacities to meet the standard of behavior of what has been called lawfulness. I will try to justify this.

Mentally ill and minors are not liable in tort in most jurisdictions. In some of them they can be liable only in an equitable way (Germany, Switzerland, Italy and Portugal); that is, according to the economical means of the persons involved.

In other jurisdictions only minors are not liable for their acts, if they are very young; the mentally ill always are (Common Law; France after 1968, the Netherlands [64]).

The decision of some statutory or case law to make insane people always liable and the difference of treatment with children give rise to some problems, which will be briefly dealt with in this context:

a) The liability of mentally ill persons is against the tradition coming from Roman law and it can lead to absurd decisions. For example, French Cour de Cassation, 4 February 1981: man in a shop who suffers a heart attack, loses consciousness and falls on a woman, causing her injuries. The inferior Court had condemned him to compensate the damages, notwithstanding his appeal that he had acted without fault, supported by the fact that he had undergone a medical check few months before. Finally the Court de Cassation overruled the inferior decision, dismissing the case on the base that losing consciousness is not a mental disorder [65].

At the bottom, the problem of blame is one of grounds of excuse. Law starts from the basic point that all citizens can behave according to certain criteria. But there are people who cannot, due to mental o physical reasons, and the European tradition is to free them from liability. It is a case of legal decision according to a moral valuation, and full of sense.

b) It is completely inconsistent to treat children and mentally ill persons in a different way. If we consider that whoever acts unlawfully has to redress the damage, it must be for everybody, no matter whether she is a child, a lunatic or a recent immigrant to south Europe who does not still know what a red traffic light means.

c) In Common Law it is frequently said, on the one hand, that "The standard of care applied to an adult suffering mental impairment or psychological disturbance remains the standard of the reasonable prudent person of normal intelligence, judgment and rationality"; on the other hand, "children are not subjected to the reasonable person standard but are instead held to a standard that is largely subjective. A minor, even an older one, is required to conduct himself only with the care of a minor of his own age, intelligence, and experience in similar circumstances" [66].

This opinion can be considered a mistake: lawfulness means a standard of behavior, no matter the personal conditions of the defendant, and the one who does not meet that standard acts unlawfully.

\section{Criticism of the Concept of Unlawfulness Presented Here}

The way of thinking presented here has other supporters (with nuances, of course), but it has been subjected to criticism. The main point is this: What is the distinction between unlawfulness and blame for, if in the end blameless actors are not held liable?

From my point of view, there are arguments which can clearly support the opinion held here:

-The principal one is the attitude of a third party when someone is acting lawfully and another unlawfully, though the latter is a minor or a mentally ill person. For example, if a mentally ill person attacks someone who is taking a peaceful stroll, the policeman who sees it has to defend the peaceful pedestrian.

-The so-called fault of the victim of the damage. Especially in the cases of strict liability, like defective products, car accidents in some jurisdictions, and so on, the damaged person has the duty, or at least the burden, of behaving according to a certain standard; otherwise, she has no right to compensation. That is, we are not talking here of an unconditional command, but of a hypothetical imperative or technical norm: if you want to have the right of compensation for the damage suffered from, behave in a certain way. For instance, if a minor swallows a large amount of pills from a bottle against the directions of use of the medicine, there is no liability of the company which makes them, despite this so-called strict liability. 
-The vicarious liability of companies for acts of their employees. The liability arises out of an unlawful act, no matter the physical or mental state of the employee is. The same can be said of the parent's liability for acts of their children. This removes the obstacles which raise polysemous expressions such as fault, faute (French) Verschulden (German and Dutch) or culpa (Italian, Portuguese, Spanish and French), so there is sometimes a distinction between faute or culpa in objective (unlawfulness) and subjective sense (blamelessness), or even force to use expressions like this: "act which would be unlawful if it was done by the standard adult" [67]. In fact, what the author wanted to express was that the action was unlawful, but not to blame two completely different things.

The second criticism that can be made of this work is that it has a very "continental" focus on the problem, which will make it useless for Common Law lawyers, and, in the end, it frustrates the desired approach to a unique law of torts in Europe.

There is no easy way out of this argument without getting into an analysis of the Common Law of torts. Anyway, I will limit myself here to make some considerations which deserve more space and depth.

The Common Law of torts is based on an old system of actions, according to which, each kind of damage has its own action, which has to be correctly put forward by the plaintiff (more or less like in classical Roman law). And, "Although the forms of action were abolished by the Judicature Acts of 1873 and 1875 an understanding of modern tort of law is impossible without an appreciation of the writ system and of the most important forms of action that developed under it" [68].

That is why there is usually no general part of tort law in Common Law books, except an introductory chapter; thereafter, each tort is addressed. So, for instance, causation is not studied generally, but as negligence; in some books, the grounds of justification or excuse are displayed for each tort, and so on.

The continental approach is more abstract, setting up basic concepts and later the problems are studied gathered together round certain common features, but without losing the general perspective. For instance, nuisance is a specific tort, whereas in continental law it is dealt with either under the right of property and the relations among neighbors or just as a set of problems in a special situation. In doing so, the concepts are not repeated, e.g., if the nuisance is intentional or negligent.

Any process of learning and researching needs concepts and abstraction (without getting into the dispute between realism and nominalism), and definitely each Common Law tort is an abstraction of ontologically unique cases. But, of course, an excess of abstraction can lead to the conceptualism of the 19th century German speaking scholars, because abstraction demands comparison, and one of the main problems of jurisprudence is the argument of analogy, because it requires identity of reason, but that identity is a matter of valuation and not of logic.

So, in the end, what really matters is a functional approach [69]. And what is humbly defended here is, first of all, that one problem is whether certain goods or values are protected or not by the law and another is that there are acts (or omissions) of human beings that can be against the law. Secondly, against the law means in tort law either intention or negligence, and ground of justification is a concept only applicable to intentional acts, because negligence in itself means unlawful. Thirdly, acting against the law is different from being excused by the law. And, finally, all these questions can arise about any tort in any of the countries considered.

\section{References}

[1] (1821) Grundlinien der Philosophie des Rechts. Facsimile Reprint, Meiner, Hamburg, 1955.

[2] (1867) Von dem Verhältnisse des strafbaren Unrechts zum Zivilunrechte. In: Merkel, A., Kriminalistische Abhandlungen, I, Leipzig, 1, 47 and 50.

[3] (1867) Das Schuldmoment im römischen Privatrecht. Collected in Vermischte Schriften juristischen Inhalts, Leipzig, $1879,159$.

[4] Roxin, C. (2006) Strafrecht. Allgemeiner Teil. I, 4th Edition, C.H. Beck, München, § 10, ns. 88 ff; Baumann, J., Weber, U. and Mitsch, W. (2003) Strafrecht. Allgemeiner Teil. 11th Edition, Gieseking, Bielefeld, § 16, n. 11.

[5] Grundmann, S. (2007) Münchener Kommentar zum Bürgerlichen Gesetzbuch. C.H. Beck, München, § 276, n. 19; Katzenmeier, Ch. (2005) Anwalt Kommentar BGB, Deutscher Anwaltverlag, § 823, n. 99; In Contrast, the Unlawfulness of the Conduct Is Defended, e.g. by Münzberg, W. (1966) Verhalten und Erfolg als Grundlagen der Rechtswidrigkeit und der Haftung, Klostermann, Frankfurt a. M., passim; Wagner, G. (2013) Münchener Kommentar zum Bürgerlichen Gesetzbuch. 5, 6th, C.H. Beck, München, § 823, ns. 4 ff.

Finally, there Is an Opinion Halfway the Two Former Ones, According to Which (and Starting from the Common Dis- 
tinction in Germany between Immediate and Indirect Damages) Unlawfulness Is Related to the Result When Speaking of Immediate Damages, and to the Conduct When Speaking of Indirect Damages. So, Looschelders, D. (2010) Schuldrecht. Besonderer Teil. 5th Edition, Vahlen, München, n. 1241; Löwisch, M. (2005) in Staudingers Kommentar zum Bürgerlichen Gesetzbuch, Sellier-de Gruyter, Berlin, § 276, n. 12; Medicus, D. and Lorenz, S. (2014) Schuldrecht II. Besoderer Teil, 17th Edition, C.H. Beck, München, n. 1241.

[6] Plescia, J. (1977) The Development of "Iniuria". Labeo, 23, 271 ff.; Pólay, E. (1985) "Iniuria dicitur omne, quod non iure fit", Bulletino del Instituto di Diritto Romano, 86, 76 ff.; Paschalidis, P. (2008) What Did Iniuria in the Lex Aquilia Actually Mean? Revue Internationale des Droits de l'Antiquité, 55, $321 \mathrm{ff}$. (Not Very Convincing)

[7] Arangio-Ruiz, V. (1958) Responsabilità contrattuale in diritto romano. Reprint of 2nd Edition, Jovene, Napoli, 226 f.; Kaser, M. (1971) Das römische Privatrecht, Vol. 1, 2nd Edition, § 41, IV, 2, p. 162 (dolus malus); Plescia, J. (note 6), 272; d'Ors, (1989) Derecho privado romano. 7th Edition, $\S \S 361$ and 374, pp. 418 and 426; Zimmermann, R. (1996). The Law of Obligations. Roman Foundations of the Civilian Tradition. Oxford University Press, Oxford, 1005.

[8] As Castresana, A. (2001) Nuevas lecturas de la responsabilidad aquiliana. Universidad de Salamanca, 51 f., states, "When Iurisprudentia Includes Intentionality and Fault as Qualifying Elements of the Human Conduct Which Causes the Result damnum, Unlawfulness Stops Being the Variable (sic) That Founds Liability for Damage and Its Place Is Taken by Culpa in Broad Sense".

[9] Bartolus a Saxoferrato (1570) In Primam Digesti Veteris Partem. Iuntas, Venetiis, 192 reverse ff. In a Quick Survey the Word iniuria Is Found Once in Four Sheets Devoted to the Lex Aquilia (in lex Liber homo, D. 9.2.37, pr.).

[10] Cujacius, J. (1758) Recitationes solemnes. In Cujacius, Opera Omnia, Pauria, Neapoli, Ad Digestum II, I, col. 90 , B.

[11] Domat, J. (1767) Les lois civiles dans leur ordre naturel. Le Breton, Paris, III, V, II, pp. 238 ff.; Pothier, R. (1835) Traité des obligations. In Dupin, M, Ed., Oeuvres de Pothier, Béchet, Paris, I, I, § II, ns. 116 ff., pp. 62 ff.

[12] Grotius, H. (1625) De iure belli ac pacis libri tres, Buon, Parisiis, Prolegomena: "Eatiamsi daremus, quod sine summo scelere dari nequit, non esse Deum, aut non curari ab eo negotia humana".

[13] Grotius, H. (1652) Inleydinge Tot de Holladtsche Regts-geleertheyt. Bouman, Amsterdam, III, 32th, p. 228. (Original Edition: 1631)

[14] Hartkamp, A.S. and Asser, C. (2006) Verbintenissen.Verbinteniss uit de wet, 12th Edition, Kluwer, $8 \mathrm{f}$.

[15] The Edition Used Here Is That of J. Meyer, Francofurti et Jenae (1680), 307-309.

[16] (1748) Fondamenta Juris Naturae et Gentium. 4th Edition, Salfeld, Halae \& Lipsiae, 1748, I, V, § XV, p. 148. First Edition from 1705.

[17] (1768) Institutiones Juris Naturae et Gentium, Officina Rengeriana. Halae \& Magdeburgicae, I, IV, $\S \S 87$ f., pp. 43 f. Original Edition 1750.

[18] Wieacker, F. (1967) Privatrechtsgeschichte der Neuzeit. 2nd Edition, Vandenhoeck \& Ruprecht, Göttingen, 206.

[19] Schlosser, H. (1982) Grundzüge der Neueren Privatrechtsgeschichte. 4th Edition, C.F. Müller, Heidelberg, 53 ff.

[20] (1697) Compendium iuris. Cottae, Tubingae, Francofurti \& Lipsiae, XLVII, I, p. 649.

[21] (1707) Cottae, Tubingae, Pars prima, Ad Legem Aquiliam, II, p. 667: "Damnum cum facientisinjuria per injuriosam rei corruptionem, (Dolovel culpa) datur".

[22] (1683) Jurisprudentia Romano-Germanica Forensis. 4th Edition, Bircknerum, Jenae, III, XXIII, I, p. 523.

[23] (1733) Elementa Iuris Civilis secundum Ordinem Institutionum. Ianssonio-Waesbergios, Amstelodami, IV, III, § MLXXX, p. 337.

[24] (1743) Elementa iurisprudentiae criminalis. 3th Edition, Halle, Facsimile Reprint, Keip Verlag, Goldbach, 1996, I, II, § XXIX, p. 17.

[25] (1808) Ausfürliche Erläuterung der Pandecten. Vol. 10, 2, Palm, Erlangen, IX, II, § 698, p. 306.

[26] Schmidt, E. (1965) Einführung in die Geschichte der deutschen Strafrechtspflege. 3rd Edition, Vandenhoeck \& Ruprecht, Göttingen, § 172, p. 173.

[27] Constitutio Criminalis Theresiana (1769) Wien. Facsimile Reprint 1975.

[28] Thus, B. Windscheid, during the Discussion of the Erste Kommission of the German Civil Code, Proposed without Success the Removal of the Requisite of the Unlawfulness. See Jakobs, H. and Schubert, W. (1983) Die Beratung des Bürgerlichen Gesetzbuchs in systematischer Zusammenstellung der unveröffentlichen Quellen. Recht der Schuldverhältnisse. III, de Gruyter, Berlin, $\S \S 823$ and 826, p. 873.

[29] von Böhmer, J.S.F. (note 24), II, XVI, § CCVI, p. 416.

[30] For example, Rein, W. (1844) Das Kriminalrecht der Römer von Romulus bis auf Justinian. Leipzig, Facsimile Reprint Scientia Verlag, Aalen, 1962. 
[31] (1900) Lehrbuch des Deutschen Strafrechts. 10th Edition, Guttentag, Berlin. He Defined Crime as "Faulty Unlawful (rechtswidrig) act".

[32] Silva, J.M. and Baldó, F. (1989) La teoría del delito en la obra de Manuel de Lardizábal. In Estudios de Derecho penal y criminología. En homenaje al profesor José Maria Rodríguez Devesa, II, UNED, Madrid, 345 ff.

[33] (1906) Die Lehre vom Verbrechen. Mohr, Tübingen.

[34] Although It Is a Fairly Widely Debated Topic. Some Think That the Explanation Is the Desire to Embrace the SoCalled Grounds of Justification. See, among Many, Fraenkel, M. (1979) Tatbestand und Zurechnung bei $\S 823$ Abs. 1 BGB, 71 ff., Putting Forward That, Although the BGB Drafters Did Not Pay Much Attention to the Topic, for It Was Considered Something Natural, in the Motive zum Vorentwurf eines BGB It Can Be Read That Damage Has to Be Compensated "Except When It Is Made an Exception in a Certain Case Because of Special Reasons" (p. 4); These Exceptions Were the So-Called Grounds of Justification (p. 13) (see Fraenkel, 100).

[35] von Bar, Ch. and Clive, E. (2009) Principles, Definitions and Model Rules of European Private Law. Draft of Common Frame of Reference. Vol. 4, Sellier, München, 3093.

[36] Koziol, H. (2010) Grundfragen des Schadenersatzrechts. Sramek, Wien, para 6/3, 172.

[37] Authors Use Here a Different Terminology, Distinguishing between Objective (Result) and Subjective (Conduct) Unlawfulness. The Former Is Maintained e.g. by Honsell, H. (2005) Schweizerisches Haftpflichtrecht. 4th edition, § 5, ns. 1 ff., Who Deems Damage Always Unlawful except When There Is a Ground of Justification; the Same Point of View Is Shared by Oftinger, K. and Stark, E. (1995) Schweizerisches Haftpflichtrecht. Vol. I, 5th Edition, § 4, n. 9, and Werro, F. (2005) La responsabilité civile. ns. 291 y 326. The Opposite Opinion Is Defended by Schwenzer, I. (2003) Schweizerisches Obligationenrecht. Allgemeiner Teil. 3rd Edition, para 50.04, p. 305, with the Arguments That It Has the Advantage That Protects Not Only Property Rights But Purely Economic Damages As Well, and That It Makes It Possible to Establish a Limit to Liability through the Introduction of Determined Duties of Care; More or Less the Same, Brehm, R. (1998) Berner Kommentar zum schweizerischen Privatrecht. Das Obligationenrecht. Vol. VI, 1; 3, 1, 2nd Edition, art 41, n. 33, p. 18 f.; Widmer, P. (1998) Function and Relevance under Swiss Law. In Koziol, H., Unification of Tort Law: Wrongfulness, Kluwer Law International, The Hague, 116, Appealing As Well to the Semantic Structure of art 41 Or in Comparison with the Italian Civil Code; Stöckli, H. (2007) Notizen zur Widerrechtlichkeit. In Niggli, M.A., Hurtado, J. and Queloz, N., Eds., Festschrift für Franz Riklin, 227 ff., Arguing That the Problem of the Purely Economic Damages Does Not Force to Accept an Objective Conception of Unlawfulness. Hesitant, Schnyder, A.K. (2003) Basler Kommentar zum Schweizerischen Privatrecht. Obligationenrecht. I, 3rd Edition, art 41, ns. 30 ff., pp. $329 \mathrm{f}$.

[38] Kortmann, C.N.J. (2006) Onrechtmatige overheidsbesluiten. Kluwer, Deventer, 22. That Was As Well the Intention of the Drafters of the Book of Obligations, Who Wrote That "In the Draft, as in the Existing Dutch Code Adopted in 1838 Wrongfulness Is Considered a Qualification of the Conduct"; see (1977) The Netherlands Civil Code. Book 6, The Law of Obligations, Draft Text and Commentary. At 6.3.1, p. 378.

[39] Asser, C., et al. (2002) Goederenrecht. Zakelijkerecht. 14th Edition, Kluwer, Deventer, 37 f. In the Same Sense, Jansen, C.H.M. (2009) Onrechtmatige daad: Algemene bepalingen. 2nd Edition, Kluwer, n. 12, p. 23; Schut, G.H.A. (1997) Onrechtmatige daad. Kluwer, Deventer, 58; van Workum, P. and Arets, L. (2007) Arrestenbundel HBO Rechten, Kluwer, at NJ 1996, 403, p. 788. Hesitant and Critical, Spier, J. (1998) Wrongfulness in the Dutch Context. In Koziol, H., Unification of Tort Law: Wrongfulness, Kluwer Law International, The Hague, $87 \mathrm{ff}$.

[40] That Is Corroborated When Reading Antunes Varela, J. (1971) Rasgos innovadores del Código civil portugués de 1966 en materia de responsabilidad civil, Madrid, 32-35. João de Matos Antunes Varela (1919-2005) Was Minister of Justice from 1954 until 1967 and the Main Promoter of the New Portuguese Civil Code, Taking an Active Part in the Code Draft. Still in Favour of the Unlawfulness of Result, de Almeida Costa, M.J. (2001) Direito das Obrigaçoes, 9th Edition, $513 \mathrm{ff}$.

[41] Teles de Menezes Leitâo, L.M. (2000) Direito das Obrigaçoes. I, Almedina, Coimbra, 257 ff.

[42] In It, It Is Literally Said That with the Unlawfulness of the Damage "It Is Made Clearer than in the Norm of the Civil Code of 1865 That Fault and Unlawfulness Are Different Concepts; and, Therefore, It Is Demanded That the Act or the Omission, to be Source of Liability, Must Be Intentional or Negligent, That Is, Imputable, and It Has to Be Carried Out through Damage to Another's Legal Sphere. It Will Be No Liability When the Damage Is Caused in Self-Defense Because Who Acts in That Case Has the Power to Defend His Own Right against the Aggressor; the Damage Caused in That Situation Cannot Be Qualified as Unlawful. In Other Words, There Is Unlawfulness When You Harm, without Justification, Another's Sphere". Quoted Following Alpa, G. (1990) Danno ingiusto e ruolo della colpa. Un profilo storico, Rivista di Diritto Civile, 36-II, $133 \mathrm{ff}$.

[43] Bianca, C.M. (2012) Diritto civile, 5, 2nd Edition, Giuffrè, Milano, n. 254; Busnelli, F.D. and Commandé, G. (1998) Wrongfulness in the Italian Legal System. In Koziol, H. (1998) Unification of Tort Law: Wrongfulness, Kluwer Law International, The Hague, 69 ff.; Inzitari, B. and Piccinini, V. (2009) La responsabilità civile. Casi e materiali, Cedam, Padova, 3 ff. The Change Is above All Based on the Air Accident Suffered by the Football Team Torino on the 4th 
May 1949 and the Damage Caused to the Club (Supreme Court Decision 4 July 1953 [1953] Foro italiano, I, 1087 ff.); up to That Moment Case Law Required for an Action in Tort Damage on Property Rights. Besides, the Same Club Suffered the Death of One of Its Players in a Car Accident, Which Set off Again the Same Problem (Supreme Court Decision 29 March 1978 [1978] Foro italiano, pp. 833 ff.).

[44] Santos Briz, J. (1963) Derecho de daños. Edersa, Madrid, 24 ff. Supreme Court Decisions of 10 September 1968 (Repertorio de jurisprudencia-hereinafter RJ-4271) and 25 October 1968 (RJ 4796).

[45] Pantaleón, F. (1991) Comentario del art. 1902. In Paz-Ares, C. et al., Eds., Comentario del Código Civil, Vol. II, 1993 ff. The Comment Had as Its Basis the Author's Ph.D., from 1981, Unpublished, Which, However, on Account of Its Quality Was Soon Circulating among Scholars Interested in Tort Law.

[46] Pantaleón, F. (Note 45), 1993-1995. Following in His Wake, e.g. Asúa, C. (2000) in Puig i Ferriol, Ll. et al., Eds., Manual de Derecho Civil. Vol. II, 3rd Edition, Marcial Pons, Madrid-Barcelona, 477; Reglero Campos, F. (2008) Tratado de Responsabilidad Civil. 4th Edition, Vol. I, Aranzadi, Cizur Menor, 59 ff.; Roca Trias, E. (2011) Derecho de daños, 6th Edition, Tirant lo Blanch, Valencia, 73; Yzquierdo Tolsada, M. (2001) Sistema de responsabilidad civil, contractual y extracontractual. Dykinson, Madrid, 110-113; etc.

[47] See Especially Busto Lago, J.M. (1998), La antijuridicidad del daño resarcible en la responsabilidad civil extracontractual, Tecnos, Madrid, passim, but 175 ff.; Albaladejo, M. (2008) Derecho Civil. II, 13th Edition, Edisofer, Madrid, 923; Bustos Pueche, J.E. (2004) La antijuridicidad, presupuesto de la responsabilidad extracontractual. La Ley, 22 September 2004, 1 ff.; Carrasco, A. (1989) Comentario al art. 1101. In Albaladejo, M., Ed., Comentarios al Código Civil y Compilaciones Forales, Edersa, Madrid, 593, on Contractual Liability; Lacruz, J.L. (1985) Elementos de Derecho Civil. Vol. II, 1. ${ }^{\circ}$, 2nd Edition, J.M. Bosch, Barcelona, 502, text and fn. 2; Martín Casals, M. and Solé, J. (2005) Fault under Spanish Law. In Widmer, P., Ed., Unification of Tort Law: Fault, Kluwer Law International, The Hague, $227 \mathrm{ff}$.; Peña López, F. (2013), Comentario al art. 1902. In Bercovitz, Ed., Comentarios al Código Civil, IX, tirant lo blanch, Valencia, 12969-70; Plaza Penadés, J. (2011) Comentario al art. 1902. In Cañizares, A., et al., Código civil comentado, IV, $1457 \mathrm{ff}$.

[48] Díez-Picazo, L. (2011) Fundamentos de Derecho civil patrimonial. V, Civitas, Madrid, 304.

[49] The Court Repeats Again and Again That "the Respect and Observance of the Administrative Provisions Do Not Exonerate from Liability the One Who Caused Nuisance, and the Administrative Regulations Do Not Change the Liability of Those Who Fulfil Them, When the Security Measures Are Not Really Enough to Avoid Harmful Events".

[50] This Strict Liability Is a Nonsense, Criticized by Many Scholars, and Usually Even Repelled by Administrative Courts (Especially in Cases of Public Administration's Medical Liability), Although Not Directly, But Using Other Arguments, Like Lack of Causation by the Defendant, Act of God, etc. The Issue Is Too Complex to Explain Here in a Few Lines. See, in English, González Pacanowska, I. (2010) The Development of Traffic Liability in Spain. In Ernst, W., Ed., The Development of Traffic Liability, Cambridge University Press, 151 ff.; González Pacanowska, I. and García-Ripoll, M. (2012) The Impact of Institutions and Professions in Spain. In Mitchell, P., Ed., The Impact of Institutions and Professions on Legal Development, Series Comparative Studies in the Development of the Law of Torts in Europe, Cambridge University Press (2012), 233 ff.

[51] Münzberg, W. (note 5), 113.

[52] Fleming, J.G. (1998) The Law of Torts. 9th Edition, LBC Information Services, Sydney, 5.

[53] Huhn, W. (2002) The Use and Limits of Syllogistic Reasoning in Briefing Cases. Santa Clara Law Review, $42,828$.

[54] Hermann, D. (1985) Legal Reasoning as Argumentation. Northern Kentucky Law Review, 12, 507.

[55] Alexy, R. (2003) On Balancing and Subsumption. A Structural Comparison. Ratio Juris, 16, 433.

[56] Kolakowsky, Quoted by Bayón Mohino, J.C. (1991) La normatividad del Derecho: Deberes jurídicos y razones para la acción. Centro de Estudios Constitucionales, Madrid, 389, fn. 200.

[57] Fleming, J.G. (note 52), 114; Dobbs, D. (2000) The Law of Torts, West Group, St. Paul, Minnesota, 275. In Spain, with regard to contractual liability, Carrasco, A. (note 47), 594. In Italy, Cian, G. (1996) Antigiuridicità e colpavolezza. Saggio per una teoria dell'illecito civile. 173.

[58] Welzel, H. (1931) Kausalität und Handlung, Zeitschrift für das gesammte Strafrechtswissenschaft, 51, 703 ff. Collected in Welzel, H., Abhandlungen zum Strafrecht und zur Rechtsphilosophie, de Gruyter, Berlin, New York, 1975, 7 ff.; (1969) Das Deutsche Strafrecht. 11th Edition, de Gruyter, Berlin, passim.

[59] Example of Roxin, C. (note 4), § 24, n. 54.

[60] In Tort Law as Much as in Criminal Law, Authors Tend to Speak Simply of "Defenses", without Any Further Distinction. See, as to Tort Law e.g. Rogers, W.V.H. (2010) Winfield and Jolowicz on Tort. 18th Edition, Sweet \& Maxwell, London, para 25-1; McBride N. and Bagshaw, R. (2005) Tort Law. 2nd Edition, Pearson-Longman, London, Devote a Special Chapter in Each Tort to "Lawful Justification or Excuse", That Is, without Distinguishing Justification and Excuse. A Good Part of Them Even Includes the Contributory Negligence among the Defenses, and, besides, as a De- 
fense inside Negligence. So, Deakin, S., Johnston, A. and Marquesinis, B. (2008), Markesinis and Deakin's Tort Law. 6th Edition, OUP, Oxford, 892 ff.; Dobbs, D. (note 57), 494 ff.; Lunney, M. and Oliphant, K. (2010) Tort Law. Texts and Materials. 4th Edition, OUP, Oxford, 300 ff.; Weir, T. (2002) Tort Law. OUP, Oxford, 119: "Contributory Negligence Is Unquestionably a Defense". But, on the One Hand, Contributory Negligence Has Nothing in Common with, Say, Insanity, and, on the Other Hand, Negligence Means per se Unlawfulness. One Thing Is Unlawfulness and Other Liability; in Case of Contributory Negligence, the Negligence of the Tortfeasor Does Not Decrease the Disvalue of the Conduct or State of Mind, But Only the Liability: Münzberg, W. (note 5), 81, fn. 161.

As to Criminal Law, e.g. Asworth, A. (2003) Principles of Criminal Law, OUP, Oxford, 204 ff.; Ormerod, D. (2005). Smith \& Hogan Criminal Law. 11th Edition, OUP, Oxford, $296 \mathrm{ff}$.

Exceptions to What Has Been Exposed Are, as to Tort Law, e.g. Dobbs, D. (note 57), 156 f. As to Criminal Law, W.R. LaFave, W.R. (2003) Criminal Law. 4th Edition, § 9.1, 447 ff.; Although Recognizing That "The Actual or Proposed Defenses in the Present Chapter Are More of a MIXED bag" (450).

[61] van der Merwe, C.G. and du Plessis, J.E. (1994) Introduction to the Law of South Africa, Kluwer Law International, The Hague, 291.

[62] Smith \& Hogan Criminal Law (Note 60), 329.

[63] The Work of McBride, N. and Bagshaw, R. (note 60), 496 ff., Is a Good Example. The Authors Treat Some Defenses under the Heading "Limits on the Right to Sue": They Include the defense volenti non fit iniuria, But According to the Civil Procedure Rules for England and Wales That Defense Is a Matter of Substantive Law and That Does Not Bar the Lawsuit from the Beginning, But It Has to Be Settled in the Final Court's Decision.

[64] In This Country Parents Are Always Held Liable If the Tortfeasor Is under 14, No Matter How Careful They Were; between 14 and 16 Parents Are Liable If They Could Have Avoided the Harm; Otherwise, the Minor Him or Herself Is Liable; That Is to Say: Someone Has to Foot the Bill, Art 6:169 BW. In Contrast, Art 6:165 Sets Out That the Circumstance That the Act Was Done under the Influence of a Mental Disorder It Is Not an Obstacle to Deem the Tortfeasor as Liable.

In France, Art 414-3 CC Lays Out That "Whoever Caused Damage to Another When He Was under a Mental Disorder Is Not Less Subjected to the Obligation of Redressing the Damage".

[65] The Facts Appear in (1979) Revue trimestrielle de droit civil, 386 f, with a comment of Durry, G.

[66] Dobbs, D. (note 57), § 120, 284 f and $§ 124,293$. The Same Opinion Is Held by Fleming, J.G. (Note 52), 126; Winfield \& Jolowicz (note 60), para 24-16; Lunney, M. and Oliphant, K. (note 60), p. 196.

[67] Pantaleón, F. (1995) Entry "Culpa”. In Montoya, A., ed., Enciclopedia Jurídica Básica, II, 1865. Compare with Art. 6:162 BW.

[68] Lunney, M. and Oliphant (note 60), 2.

[69] See Koziol, H. (1998) Conclusions. In Koziol, H., Unification of Tort Law: Wrongfulness, Kluwer Law International, The Hague, 130. See Also the Seminal Work of Viehweg, T. (1953) Topik und Jurisprudence. C.H. Beck, München. 